\title{
The Importance of Placing Blame: Criminal Law and the Stabilization of Norms
}

\section{Monika Simmler}

\section{Criminal Law Forum}

The Official Journal of the Society for

the Reform of Criminal Law

\section{ISSN 1046-8374}

Volume 31

Number 2

Crim Law Forum (2020) 31:147-178

DOI 10.1007/s10609-020-09390-1 
Your article is protected by copyright and all rights are held exclusively by Springer Nature B.V.. This e-offprint is for personal use only and shall not be self-archived in electronic repositories. If you wish to self-archive your article, please use the accepted manuscript version for posting on your own website. You may further deposit the accepted manuscript version in any repository, provided it is only made publicly available $\mathbf{1 2}$ months after official publication or later and provided acknowledgement is given to the original source of publication and a link is inserted to the published article on Springer's website. The link must be accompanied by the following text: "The final publication is available at link.springer.com". 

AND THE STABILIZATION OF NORMS

\begin{abstract}
This article argues that the function of criminal law and of punishment consists in stabilizing norms by ascribing culpability. A theoretical and sociological examination of the mechanism of placing blame reveals that it consists of three elements. Blame is placed only if a capable addressee of norms is present (personhood), if this person was in the time of offending competent enough to question a norm (competence), and if this person actually communicated a negation of this norm (message). If these requirements are met, an act destabilizes the norm effectively, and punishment becomes necessary. The fault requirement therefore is crucial for fulfilling criminal law's function, i.e. the stabilization of norms within society by means of punishment. In outlining the social importance of placing blame, this article establishes a basis for both a sociological approach to and a normative discussion regarding theories of punishment and of responsibility, and discloses that respecting the principle of culpability is not only an expression of justice but also one of social necessity.
\end{abstract}

\title{
I INTRODUCTION
}

Hundreds of years of debate about the nature of blameworthiness in criminal law and elsewhere have not brought us any closer to something we could call a consensus on its precise conception. A short glance at the theoretical discussions in different legal orders clearly confirms this impression. Still, all Western legal orders know something called the principle of culpability or principle of fault, even though its standing and its concrete implementation may differ from one legal order to another. The arguments surrounding this theoretical debate and the doctrines potentially interfering with it (e.g.,

\footnotetext{
* Monika Simmler, Postdoctoral Fellow and Lecturer in Criminal Law, Criminology and the Sociology of Law, University of St. Gallen, Law School, Switzerland. Email: monika.simmler@unisg.ch.
} 
strict liability) highlight that we are dealing with an issue that reflects moral and political conflicts.

In order to shed some light on the relevance of the principle of culpability, its claims and its legitimacy, I suggest going back to the fundamental questions of criminal law theory: What is the social function of the criminal law system? Why do we even have criminal law in society? What is the purpose of punishment as its main characteristic and what is the role of personal fault within this framework?

As the emphasis on the system's function already suggests, the argument presented in this paper relies on a functional, i.e. on a sociological analysis. This sociological analysis will be conducted through the lens of systems theory. ${ }^{1}$ This approach, which will be outlined in short in the following, allows placing social systems and their main features at the center of the analysis. Following this epistemic framework of systems theory creates the possibility of systematically identifying the social mechanisms surrounding both punishment and the attribution of personal responsibility. In doing so, sociological thinking is added to a debate that has been dominated by traditional philosophical legal thought. Additionally, its contribution consists in the analysis of a system that so far has not often been in the center of attention of sociological systems theory: criminal law.

This article thus consists of five main parts. First, it briefly analyzes criminal law as a social system, including an examination of its function (II.). Building on that, the mechanism of placing blame as the system's modus operandi is analyzed in detail (III.). After shedding light on this mechanism and defining the relevant elements within the process of placing blame, these descriptive sociological findings then lay the foundation for the discussion of the way the boundaries and the function of criminal law systemically interrelate to each other (IV.) as well as the discussion of the normative implications for legal doctrine (V.). This exploration, hence, does not stop at describing criminal law's position within society and its operations as they can be observed today. In disclosing the purpose of punishment and the social importance of placing blame, it aims at contributing to a critical reflection on criminal law and on its standing. Likewise, these observations shall serve as a productive ground for appraising criminal law's doctrines concretely. After all, placing blame is not an

\footnotetext{
${ }^{1}$ This analysis relies relevantly on the author's previous work, published in German. See Simmler (2018).
} 
end in itself. It serves a specific function within our social order. This is why it is legitimate. This is why it is important.

\section{FUNCTION OF CRIMINAL LAW}

\subsection{Systems Theory and its Capacity of Capturing the Criminal Law}

Social scientific analysis of systems can be an approach that allows to better understand, how a world of chaos and coincidences is building and maintaining social order (Röhl 2001, 421). So-called systems thinking, which has been established and spread over the past 100 years in a set of very different fields of research, has also reached legal theory, mainly based on Gunther Teubner's (Teubner 1993) and even more pronounced Niklas Luhmann's (Luhmann 2004) contributions. Luhmann's approach aligns with other functionalist approaches focusing on the main assumption that social systems only emerge because there is a need for the fulfillment of a specific function within society. ${ }^{2}$ Social systems can be seen as a result of the historical growth of a variety of society's conditions and as a consequence of the need to reduce complexity (Mastronardi 2009, 171-72). Given that, the legal system is presumed to be a sub-system of society that originates from the need to fulfil a specific function. Therefore, the legal system has to be conceived and analyzed with regard to the overall system (Bleckmann 2002, 4-5). This conception offers a clear epistemic framework. It also provides a solid foundation for a critical-emancipatory position. It does so because the empirical material gained from observing social functioning can serve as a basis for questioning social processes as well as their value for the social order (Luhmann 1995a). In this sense, this lens appears to be promising regarding the research question at hand. It can help to analyze the function of criminal law and the requirement of personal guilt. Doing so, the overall social order must always be borne in mind.

There are, of course, certain assumptions that go hand in hand with accepting systems theory as an adequate benchmark. The focus

\footnotetext{
${ }^{2}$ It should be noted that there is an important difference between functionalist analysis as a matter of social theory and functional or consequentialist approaches in legal scholarship or doctrine. Neither do they depend on nor exclude each other. It is one thing to ask for the social function of an institution and the reason for its emergence in a sociological manner and another to imply that functionalism has to be used in the practical application of the law. Therefore, functionalism and varieties of instrumentalism should not be confused.
} 
on sociality (and therefore on interaction, i.e. more precisely on communication as the system's elements ${ }^{3}$ ) and a descriptive functionalism result in a rejection of the concept of eternal truth, independent of time, place and existing order (Amstutz \& FischerLescano 2013, 9). Besides this constructivist perception, some form of legal positivism is also inherent in an approach informed by systems theory. The operative closure of social systems makes them a selfdetermined unity. ${ }^{4}$ This does not mean that influences of other systems are impossible. For example, no one would deny the importance of the political system for criminal law. However, other systems can only influence the law by means of structural coupling, i.e. by systemic interrelations. They cannot do so by causal determination. Therefore, the criminal law system has to be seen as a unit defining its own function and its own boundaries within its superior system(s) law and society. In following its differentiation, i.e. its function, only the system itself decides which communications are recognized as relevant events and hence are to be considered. Based on this, the system decides what kind of punishment, if any, results as an outcome of the system's procedures. This statement sets limits to approaches conceiving non-positivist causal links between e.g. the law, legal responsibility and metaphysical morality. Especially with regard to blameworthiness, abandoning the idea of a moral foundation and focusing on the observation of the social purpose of the ascription of personal fault for upholding social order instead may seem surprising at first. Indeed, this approach seems to be merely relativist and could be suspected to justify every possible meaning of guilt. However, this social relativism and its inherent de-mystification of seemingly selfevident truths are necessary for laying the grounds for the proposed normative conception of guilt. Only such a conception is based on the social system itself and offers guidance in accordance with the existing social order.

Thus, the emergence and persistence of the principle of culpability and the criminal law's mechanism of placing blame shall primarily be assessed as a social factum. It is necessary to accept that social sys-

\footnotetext{
${ }^{3}$ The operation of communication should not be understood as a form of speech act of an individual or the like. Communication in this broader sense is every selective operation, which composes a synthesis of "information, message and comprehension". A certain conduct for example is already more than this basal element, because acts are already an imputation of communication and therefore not the smallest elements of a social system. See Luhmann (1995a, 137-75).

${ }^{4}$ See for a discussion of system's self-referential (autopoietic) closure Luhmann (1995a, 37-38). The term autopoiesis was introduced by Maturana \& Varela (1980).
} 
tems follow their functions in ways dictated by their own modalities. So does criminal law in its distinct mechanisms of holding people accountable, which shall be outlined here through the lens of systems theory. The following chapters will provide an overview of the theory's main tenets. This overview is limited to what is necessary for the research question at hand. This will provide the starting point for a systematic analysis of the standing of culpability in criminal law and, thus, in society.

\subsection{Differentiation of Functional Systems}

Systems theory focusses differentiation and builds on the guiding difference between a system and its environment (Luhmann 1995a, 16). The aim of this method is to find the unique function, which distinguishes a certain social system from other systems (social, technical or psychic ones). Only these functional differentiations make systems distinct from each other and allow for a further increase in complexity. A system in this sense is a self-contained entity, which possesses the ability to reproduce itself and to distinguish itself from its environment in doing so. The purpose-driven relationship and arrangement of its elements lead to a limitation of the domain of possibilities. This conditioning reveals the specific characteristics of a system, which is therefore in classical terminology more than the sum of its parts (Luhmann 1995a, 22, 133; Hall \& Fagen 1956, 18; Röhl 2001, 421-22). Thus, social systems reduce complexity by means of selection. This selection imposes order on the infinite number of possible events and such order is needed for social differentiation (Luhmann 1995a, 32).

Society is a social system, the overall social system to be more precise (Luhmann 1995a, 12, 34). It is in this society that a legal system emerges. Grasping this legal system means understanding its function ${ }^{5}$ for the continued existence of society. The point of reference of a functional analysis consequently lies in the superior system. Why did society differentiate a legal system? What purpose does it serve? Why is there a statutory standardization and what is its role in

\footnotetext{
${ }^{5}$ There is a wide use of the term function in different scientific fields. I use it to describe the contribution of a certain social institution with regard to a specific need of society as the overall social system. Therefore, the idea of a function is one of social theory. About this classic sociological use of the term as a matter of functional analysis, see, e.g., Luhmann (1995a, 52-58) and Merton (1957). I furthermore use the terms purpose and aim synonymously and likewise not in a normatively loaded understanding.
} 
organizing social order? What distinguishes this function from other modes of order? These questions cannot only be asked for the legal system as a sub-system of society, but also for the criminal law system, which constitutes a sub-system of the legal system. ${ }^{6}$

Talcott Parsons, one of the founders of modern sociological systems theory, identifies the law as one way of social control and consequently social integration as the main purpose of law (Parsons 1962, 56). While Parsons only provided a very abstract definition of norms and standardization, Luhmann stated in a very detailed manner how normalization of behavior and mutual orientation regarding norms are placed at the center of the functional emergence of the legal system. In his conception, the function of the law is the systemic (counterfactual) stabilization of normative expectations allowing the emergence of social order with a high degree of complexity (Luhmann 2004, 142-72). The constituting element of the legal system is every communication that is oriented towards a differentiation by means of the binary code legal/illegal. Every operation that is not oriented towards this code belongs to the system's environment. According to Luhmann, this mode of operation and aim allows the legal system to operatively distinguish itself from other social systems (Luhmann 2004, 173-96).

Criminal law, too, like every other social (sub-)system, is defined not only by means of its function but also by the possibility of differentiating itself from its environment (Luhmann 1995a, 16-19, 176). As a key of systems analysis, this boundary does not mark a complete break in connections or interrelations, but sets a decisive threshold, which characterizes the distinctiveness of a system and which cannot be crossed without a change in process conditions (Luhmann 1995a, 17). Of course, as will be discussed later, the function of a system and its boundary stand in close interrelation. Still, the boundary itself plays an important role not only in defining possible dependence and interaction of criminal law with its social environment, for example its structural coupling (Luhmann 1992, 13) with the political system or the moral system of a society, but also in defining criminal law's limits regarding other areas of law following another, distinctive

\footnotetext{
${ }^{6}$ It should already have become clear that system in that sense does not refer to the system of legal doctrine (e.g. the structure of offenses) or the system of penal provisions in statutes, but instead to a social system of communication (as elements) regarding a certain function. The previous mentioned structures are rather a result of the increased request of the social system to organize its elements to fulfil its aim. On the essence of legal dogmatics from this functional perspective, see generally Luhmann $(2004,257-58)$.
} 
function and therefore presenting different sub-systems of the legal system. Hence, it must be clarified subsequently what the distinctive function of criminal law is. This allows to determine the relevant boundaries and to differentiate criminal law from other legal and non-legal systems.

\subsection{Normative Expectations and their Stabilization}

The "normative construction of society" (Popitz 1980) originates from a phenomenon Luhmann (1995a, 103) - taking up Parsons (1951) - introduces as double contingency, which he calls the basic condition for social interaction per se. Understanding this phenomenon means not only understanding socialization but also understanding the emergence of a legal system in society. Contingency is what is "neither necessary nor impossible", and what is therefore "just what it is (or was or will be), though it could also be otherwise" (Luhmann 1995a, 106). Consequently, the term refers to something that exists in the light of the possibility of being otherwise (Luhmann 1995a, 106). In the basic constellation of double contingency, two systems (e.g. individuals as psychological systems), which are not completely transparent and predictable for each other (Luhmann calls them "black boxes"), come into conflict (Bleckmann 2002, 85; Luhmann 1995a, 109-12). These actors are self-determined and, because of their non-predictability, a situation of uncertainty arises on both sides. In case of an absence of any norms, these alter and ego would proceed by assuming the behavior of each other by means of mutually changing their perspective. This leads to expectations on both sides and to a coordination of behavior in a situation, which is fully contingent (Luhmann 1995a, 390). Social systems now result from the fact that both actors experience this phenomenon of uncertainty, which usually increases structural formation in order to minimize contingency in the future. Actors will learn by observation and make their behavior more and more predictable by developing regularity and order (Luhmann 1995a, 105, 108). This order limits contingency for future operations and allows for social formation. Once established, this order serves as a ground for normative expectations regarding the behavior of other actors. The resolution of the unsatisfying situation of permanent contingency therefore results in a coordination of behavior and conduct (Bleckmann 2002, 85). Hence, social structures are nothing other than structures of expectations (Bleckmann 2002, 109; Luhmann 1995a, 293). Such expectations become generalized and subsequently normative because the 
symptom of contingency has to be resolved and the complexity of coordination has to be reduced (Luhmann 1995a, 97). Paradoxically, it is this reduction of complexity that allows for a further differentiation of society including an increase of social complexity in general.

The description of these mechanisms of socialization appears widely logical. Still, it is important to go back to this fundamental question to understand what makes not only law but criminal law a distinct social system. As society's "immune system", the legal system owes its relevance to the described need for structuring expectations (Luhmann 2004, 48). As I have already discussed, functional social systems emerge in regard to a special contribution they provide for the overall system. They have to solve a specific problem. (Luhmann 2004,142 ). In a system with a potentially endless amount of alternative behaviors, the reduction of social complexity by means of the standardization of norms is a necessary condition for the continuation of society (Killias 1980, 31-34). Social order asks for non-arbitrariness (Luhmann 1974, 49). However, no social order can guarantee the fulfillment of all arisen expectations. The disappointment of expectations as an inevitable symptom leads to difficulties for the social order, which have to be overcome (Luhmann 1995b, 251). This brings us to the main function of the legal system: the counterfactual stabilization of normative expectations (Luhmann 1995b, 252).

The point of departure for this mechanism is the conception of different types of norms. There are two kinds of expectations: $\operatorname{cog}$ nitive and normative expectations. The first type concerns expectations that are called cognitive because in the case of a disappointment of these expectations the dissatisfaction cannot be ascribed to a specific faulty person or conduct. This impossibility of imputation results in the need for relearning. Since the expectation cannot be upheld, this kind of miscalculation usually provokes a poena naturalis and expectations have to be adjusted for the future (Jakobs 1993, 6-8; Bleckmann 2002, 111-12). Normative expectations are a different case (Luhmann 2004, 94, 149-53). They are upheld even if the expectations are not met. Actors counterfactually stick to their expectations, given that they can identify the disappointment as a mistake, that they can ascribe this mistake to another actor and that they can rely on the support of the social system in doing so (Jakobs 1976, 9-10; Jakobs 1993, 7). The strongest support in this counterfactual continuation for a specific set of norms is the one offered by law (Luhmann 2004, 142-72). 
The legal system cannot promise normative behavior. It can only stabilize expectations by protecting the people who expect such behavior (Luhmann 2004, 146). Without the protection of a certain stock of norms by the legal system, social order could not persist in a world of unbearable contingency. The law allows us to live with unrealized expectations by protecting and upholding them even in cases of disappointment (Luhmann 1981, 41). Labelling a disappointment as a mistake is crucial for upholding normative expectations, especially in the field of criminal law. The disappointment of a normative expectation leads to a situation of conflict. Society and other social sub-systems make use of the legal system to resolve this kind of conflict (Bleckmann 2002, 120-21). No other social system can provide certainty regarding the question of whether one can rely on social backing for a certain expectation or not. This is the distinctive and overall function of the law as a social system. The legal system performs this function by way of operations specific to it and by way of making decisions according to the code legal/illegal. In performing this function, the social system acts in an autonomous and self-determined manner (Luhmann 2004, 76-141). No other system can answer the question of the legality or illegality of an act and no other system can interfere with the answer to this question once the conflict is part of the legal system. There is no "other authority in society, which can proclaim: this is legal and this is illegal" (Luhmann 2004, 100) and therefore, nothing else can secure the stability of normative expectations in this unique and powerful way.

\subsection{Criminal Law as a Social System}

As social systems develop and thereby gain complexity, these systems themselves differentiate into different sub-systems. In the case of the legal system, this is commonly understood to mean a differentiation of distinctive areas of law (Theile 2009, 57, 68). This differentiation does not necessarily follow the systematization of the statutes itself (Durkheim 1984, 28). A field of law can only be properly called a social system in a functionalist sense if it has its own distinctive function. Therefore, to ask if criminal law constitutes an own social system demands an answer to the question of whether it serves a social purpose, which can be distinguished from the social purpose of other fields of law and which allows for defining clearly the boundaries of the system (Kleinfeld 2016, 1486). In other words, has criminal law emerged to guarantee the stabilization of a distinct kind 
of norms? Or rather: Has it emerged to stabilize these norms in a distinct way? The answer is yes and, not surprisingly, this stands in a close relationship with the purpose of punishment.

The violation of a criminal provision disappoints a normative expectation within society, which consists of the assumption that this kind of violating conduct has not to be foreseen (Theile 2009, 81-82). The distinctiveness of the criminal law norm compared to other norms now lies in the prospect of a specific sanction in the case of disappointment. This prospect relies on the specific symbolic apparatus of punishment, which allows one to recognize clearly if one's behavioral expectations are in accordance with the law or not (Luhmann 2004, 150). Punishment becomes a substitute for compliance, which is offered by criminal law to guarantee on-going reliability of expectations (Luhmann 2004, 164-65). While private law focuses on correcting damages resulting from breached norms, the criminal legal norm offers orientation for social interaction, preventing this interaction from being an incalculable risk by means of the threat of sanctioning in the case of non-compliance with the normative expectation (Hörnle 2013, 53).

However, every legal norm can be defined as a "rule of behavior to which sanctions apply" (Durkheim 1984, 28). Private law and particularly tort law also offers a counterfactual enforcement as an answer to disappointed normative expectations. However, this answer differs depending on the position a norm has in the social order. While the punitive answer of criminal law would, as Durkheim puts it, rely on a harm, injury or disadvantage imposed on the perpetrator, private law would consist of the adjustment or re-establishment of things or in "restoring the previous state of affairs" (Durkheim 1984, 29). An act would only be considered criminal when it violates a certain state of collective consciousness or common sentiments, in his classical terminology the "moral consciousness of nations" (Durkheim 1984, 31-34). Apart from this rather general foundation, it can be stated in a more positivistic manner that the distinctiveness of the criminal legal norm lies in the included threat of punishment as a specific answer to non-compliance. Therefore, the function of the criminal law system is to stabilize norms by means of the specific instrument of punishment. Due to this instrument, it generally guarantees a stronger assurance of certain norms than other legal sub-systems will ever be able to guarantee. What norms have to be assured with this strength is to be answered by political philosophy (and in consequence decided by the political system due to certain 
defined needs within the social system). For the purpose of this analysis, however, the observation is crucial that the normative expectations, which guide the communication of the criminal law system, are those for whose violation punishment is foreseen. Punishment therefore acts as the identity-creating element of this social system. By using the binary code of criminal/non-criminal, the overall function of criminal law is determining and answer the cases of normative disappointments, which demand punishment in order to stabilize the norm.

\subsection{Purpose of Punishment}

Purpose and justification of punishment are widely considered to be the main point of departure of criminal law theory (Kleinfeld 2016, 1497). This article does not aim to offer an overview of all existing theories of punishment. Instead, I head directly to the already presented argument that the purpose of punishment as the distinctive feature of criminal law has to be considered within the scope of the legal system's overall function of stabilizing normative expectations. While theories of retribution, deterrence, rehabilitation and incapacitation surely offer important insights on the manifest and latent contributions of criminal law, they do not address the main function in a sociological sense. ${ }^{7}$

A norm defining a criminal offense including its specific character of providing a threat of punishment is dedicated especially to symbolically emphasize the secure fixation of expectations (Jakobs 1993, 9-10; Gómez-Jara Díez, 2005, 330). Some behavioral expectations can only be ensured with this backup of sanctioning. As expressive punishment theories also suggest, punishment answers a criminal offense by calling someone to account (Duff 2001, 27-30). Punishment as the system's output counterfactually demonstrates the validity of the norm in question and restates its meaning by defining the conduct as mistake (Jakobs 1993, 6). Main addressees respectively audience of criminal norms and, by extension, of the punishment are therefore not primarily offenders or potential offenders but rather norm-conforming citizens, whose normative order must be preserved.

\footnotetext{
${ }^{7}$ This does not mean that other benefits of punishment should be ignored or that these theories are of no value. Instead, they just address another level of analysis and cannot explain the emergence of criminal law in the social system. It therefore should be differentiated between function in a sociological sense and further contributions of a system. This distinction is widely accepted in sociological theory; see on the impossibility of following different key functions Luhmann (2004, 148-49).
} 
This results in a systems theoretical formulation of positive general prevention (Jakobs 1976). Punishment strengthens and reactivates the normative identity of society (Popitz 1980; Schneider 2004, 312; Jakobs 2004, 491). Remaining silent after a conducted wrong would undermine the declared meaning of the norm in question (Duff 2001, 28). Without the reinforcement through punishment, the validity of the norm would be at risk in the future. In case of frequent recurrence, norms could erode and the stability of the normative structure would be jeopardized.

Sanctioning violators guarantees the permanent reproduction of the validity of norms. Punishment stabilizes the norm that has been questioned. It negates what the offense communicates (Kleinfeld 2016, 1513). It compensates for the loss of confidence of the community provoked by the disappointment and maintains the normative structure. This normative structure could not be provided if society would not manage to organize a reaction to a violation (Popitz 1980, 64). This formulation of positive general prevention can be distinguished from other theories of punishment. ${ }^{8}$ It is general because it does not primarily serve as an influencing factor to the individual offender but rather to the community as a whole. It is positive because it counts on the reinforcement of the social bond to strengthen the internalization of norms and to increase their acceptance (Baurmann 1998). This leads to its preventive effect, in the form of the future orientation in reducing the risk of a drift of the norm and further violations. Still, this terminology can be criticized. The outlined preventive effect should not be misunderstood in a consequentialist manner. Punishment is determined by the past. It is an answer to something that has already occurred, a reaction to a disappointment of expectations. In this sense, it is the disappointment that triggers punishment, and not primarily the punishment's utility for the future. Punishment is a process of coming to terms with the past to guarantee a future survival of the normative expectation. ${ }^{9}$ Positive general prevention can therefore also be called reconstructivism as suggested by Kleinfeld (2016, 1486-1565). This term is not

\footnotetext{
${ }^{8}$ It has to be pointed out that there is not something like one single understanding of the concept of positive general prevention. Many different theories and works especially in the German literature - are using this label, sharing a main idea in their core but not always identical concepts. See for an overview of these theories, e.g., Wachter $(2015,92)$ trying to categorize the different theories of German authors.

${ }^{9}$ It therefore cannot easily be categorized in the classic distinction of absolute and relative or retributivist and consequentialist theories.
} 
entirely ideal, either. Of course, as we have seen, punishment is determined to reconstruct an endangered norm. But the term can be misread in ways that the norm is already invalidated in the case of the offense while it is not. It is questioned and challenged, but answering with punishment guarantees that the norm is not destructed in the first place. Thus, the norm is preserved before reconstruction would become necessary. Just to clarify matters, it offers stabilization, not reconstruction. Thus, I will henceforth call the purpose of punishment in line with the function of the overall legal system the stabilization of norms or more precisely: the stabilization of normative expectations.

The previous statements can be summarized as follows: Criminal law is a distinct social system. As a sub-system of the legal system, this sub-system's main function is to define the cases where a normative destabilization asks for punishment and to offer this output by using the criminal/non-criminal distinction. The purpose of punishment lies in a powerful way of stabilizing normative expectations within the social order. Punishment is an answer to a normative disappointment and therefore determined by the past while being aimed to serve for the future upholding of the norm. But why does criminal law, in following this purpose, demand personal fault and has established the principle of culpability? Is placing personal blame indispensable for the fulfillment of criminal law's function of normative stabilization by means of punishment? And if so, according to which principles does the social system place it?

\section{MECHANISM OF PLACING BLAME}

\subsection{Principle of Culpability and Fault Requirement}

Nulla poena sine culpa - or actus non facit reum nisi mens sit rea as it is more often cited in English literature - is widely recognized as not just one but rather the main guideline for criminal law. This principle states that there cannot be a conviction without culpability. But that is already where the consensus ends. What exactly the principle of culpability includes, what fault in that sense really means and how strictly it must be pursued, is probably one of the most discussed topics in criminal law theory after all. I do not aim to reproduce all arguments brought up in this context, reaching from general philosophical debates about free will as a main fundament of guilt to concrete questioning of the doctrines of wrongdoing. Rather, I will 
follow the functionalist analysis focusing on the substance of the principle itself before laying out the elements and specific mechanisms of placing blame.

As I have already discussed, the specific character of criminal law's answer to a breach of normative expectations consists not primarily in compensating the advantage an offender may have gotten or to undo the damage she or he has caused but rather in underlining the validity of the norm for the future by communicating non-acceptance of the breach (Jakobs 1993, 9-10, 35). Punishment is therefore especially suited to stabilize norms by labelling a previous destabilization as a mistake, a disappointment and a breach. For considering a disappointment as a mistake, it is necessary to ascribe the destabilizing communication to an actor. Only a breach, which can be imputed to an actor, is suitable for a proceeding stabilization. If the disappointment cannot be explained by the mistake of such an actor, it is experienced as a cognitive disappointment, which asks for relearning, or is not experiences as a disappointment at all, because the validity of the norm has not been questioned and the disappointment can be explained otherwise. Criminal law's personal imputation processes therefore arise from the distinction of nature and meaning expressed by the offender (Jakobs 2004).

This leads us to the first essence of the principle of culpability: Defining the cases in which a norm has been destabilized because this destabilization can be identified as a mistake and imputed to a concrete actor. This component of the principle offers the justification for (by revealing the need of) punishment in the first place. Only if a norm is at risk for being deconstructed, which is only the case if the disappointment can be imputed to an offender and if it cannot be explained otherwise, punishment becomes necessary and therefore legitimate. ${ }^{10}$ Placing blame in that sense requires certain elements. The social system does not impute fault randomly. It follows a

\footnotetext{
${ }^{10}$ This observation of the social functioning of criminal law and of the examined principle can be criticized with the objection that social necessity does not serve to justify punishment as interference with individual autonomy. Indeed, the approach is mainly sociological in that sense. However, a philosophical and therefore normative justification can be based on that approach, too - from a liberal standpoint as well as from a communitarian. The focus on social order and the use of punishment in providing this order can be justified with the original value of the social system itself or by the value of its guarantee as a necessary condition for the free individual development. This thought cannot be further explored here, but should serve as an idea how a normative theory could possibly lie on the grounds of this functionalist observation.
} 
specific logic in doing so, which I will examine below. But before that, I want to shortly address the second essence of the principle, which builds on the first one. Once a case can be defined as one of normative destabilization, the principle offers further guidance in asking for proportionality of the punishment regarding the degree of destabilization. ${ }^{11}$ Only an adequate sentencing, which is proportional to the caused destabilization, can be justified within the demands of the principle of culpability. This second element of the principle becomes highly relevant, especially for determining the severity of punishment. However, it should be stated here that placing blame is primarily something binary: There is an identified fault or there is not. There is a threat to normative destabilization or there is not. Yet, the operations that are secondary to this primary application of the code are not binary but rather variable. The spirit of the fault requirement in that second sense is therefore a gradual one and in its gradation, it is highly complex.

Understanding the mechanism of the fault requirement within the functioning of the criminal law system asks for a further exploration of the mechanisms guiding that requirement. It should have already become clear that placing blame in the descriptive sense of this examination does not necessarily have to be identical with the categories of legal scholarship and doctrine. A view on different legal orders can support this point. In the doctrine of Common Law countries, it is distinguished between actus reus, mens rea and defenses. However, there is no clear doctrine which of these elements are the fault elements, and which are not, mainly because the doctrine is relevantly shaped by procedural questions and led by pragmatic considerations. The difference between wrongfulness and blameworthiness is surely known and discussed as well (Gardner 2005, 51), but has not influenced the structure of offenses as it has for example in German doctrine. ${ }^{12}$ In German speaking countries, this structure contains objective elements of the offense, subjective elements of the offense, justification and culpability. Still, there is also a lack of clear consensus regarding the question of which elements form the fault-

${ }^{11}$ This principle of proportionality is widely recognized as a touchstone of sentencing. It is understood as a principle stating that punishment must stand in an appropriate relation to the wrongdoing and fault and that punishment therefore is limited by personal responsibility. See Ashworth $(2011,535)$ and Brown $(2012,109)$.

${ }^{12}$ This development was mainly influenced by the so-called finale Handlungslehre, which can be described in English as a "teleological theory" of human action. See Fletcher (1998, 52) and Welzel (1969). 


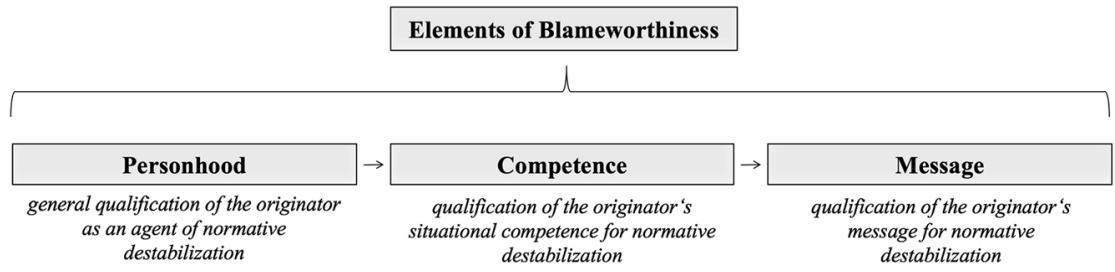

Figure. 1. Elements of Blameworthiness

part of the offense (e.g. if that should be understood in a broader or narrower manner) or what culpability in that sense really means. As a result, I will sort out my subsequent examination of the elements of placing blame not based on the doctrinal structure of the offense, but rather on describing the social function preceding this structure.

\subsection{Elements of Blameworthiness}

As we have seen, the capacity of the fault requirement consists of the capacity of identifying the actor who has to be punished as well as of identifying the degree of punishment necessary (Jakobs 1993, 480-81). This imputation of culpability relies directly on the social process of the stabilization of norms. It is only constituted by the preceding interference with the recognition of the norm asking for a stabilization as a response. Consequently, the role of culpability in the social system of criminal law is to identify if there is a destabilization of a norm, which asks for punishment, and to what extent such a destabilization is present. Within this process, certain elements can be defined, which form the fundamental conditions of placing blame. Looking at the social mechanisms of the criminal law system, these can be identified as the on-going premises of the system's process of imputation. As the chart below introduces, the purpose of blameworthiness is to mark the cases in which a disappointment of normative expectations has occurred due to an individual's fault (Figure 1). Otherwise, no destabilization is imminent and no punishment is necessary.

To qualify as blameworthy, the act needs to be perceived as a communication questioning the validity of the norm (message element). Furthermore, this act of questioning has to be ascribed to a person who is an adequate audience, i.e. addressee of normative communication within the system and therefore has the capacity to destabilize norms in the first place (personhood element). In addition, it must be determined that the disappointment cannot be explained otherwise than by this person's mistake in this very concrete situa- 
tion, i.e. that the person had the situational capacities and possibilities to prevent the breach in the given context (competence element). We can only declare someone responsible for the disappointment of a norm if these three elements are given, because it is only in this case that such a disappointment can be explained by personal fault. Only if we do so, a destabilization of the norm has occurred at all and cannot be averted simply with a reference to other external causes. It is then an attack on the validity of the norm. It is a blameworthy act that asks for punishment as a suitable reaction in order to re-activate the norm.

I will examine these three elements and their substance more precisely in the following sections. However, I already endeavor to emphasize that the arrangement of the chart and the separate discussion of the elements should not misguidedly lead to the conclusion that there is a single order in which the elements can be placed or that the elements are completely independent from each other. Rather, the elements are connected and build a single process of imputation of the communication at hand. To give an example: If the originator of the act is a qualified sender of the destabilizing communication and the act itself is furthermore qualified to communicate the invalidity of the norm, but this communication can be explained otherwise, the norm can be stabilized by the means of this other explanation and punishment remains unnecessary. An alternative explanation means that there is an excuse, i.e. an exceptional circumstance to take into account, which allows to explain the disappointing act in that very situation otherwise than by personal fault (e.g. through involuntary intoxication). Other examples, where one of the other elements is missing, could be easily found. Only if all of the elements are present, the norm is successfully destabilized.

\subsubsection{Personhood Element}

As stated above, no element exceeds another in its importance. Still, I will start with the personhood element as the most fundamental condition of personal responsibility. Processes of imputation are highly relevant in every social system. Law does not take place in individual consciousness but rather in interaction, in communication (Jakobs 1995, 867). Every act is nothing more than an attribution of an operation (communication) to a certain person in the system. The relevance of this procedure of imputation requires a closer look at the concept of personality or personhood in social systems, and should not 
be identified automatically with an ontological understanding of individuals. The concept of personhood is important for the discussed theory construction. Normative expectations are only directed towards persons in this systemic sense. Only addressees that are experienced as a suitable audience have the ability to disappoint the expectations linked to them. Therefore, only actors who have a sufficient quality of personhood can serve as a point of reference for imputation and can be held responsible. ${ }^{13}$ Personhood includes a social role and an attributed general competence (Jakobs 1995, 859; Luhmann 1995a, 108). Personhood therefore is a social construction, a social fact (Bleckmann 2002, 104-05). The communicative construction of a normative audience is a crucial requirement for the normative structuring of society. Personalization is therefore a mandatory process for every type of attribution of responsibility.

There is no doubt about the relationship between the emergence of different forms of subjectivity and personal responsibility (Farmer 2016, 164). The spirit of individual responsibility asks for a personalization of wrongfulness. The principle of culpability ensures this personal reference while protecting the individual from being mobilized arbitrarily. Analyzing to whom we ascribe personhood from a criminal law perspective is often - but not necessarily - connected with the discussion about free will as a fundament of personal responsibility. ${ }^{14}$ Following the prevailing assumption, only an individual who had the chance and capacity to act differently shall be held responsible for her or his act. As already influentially stated by Hart, a person should only be blamed if she or he had the capacity to conform with the law's expectations and if he or she could have chosen to act otherwise (Barry 1999, 197; Hart 2008, 152). However, this capacity is barely based on the fact that someone actually had a free will and was completely undetermined in her or his actions. Rather we attribute this capacity to a person in social interaction. In a society structured by norms, persons are constructed addressees of rights and duties (Jakobs 2005, 266). Criminal legal personhood is a construction of observers, a summary of expectations (Luhmann 1995a, 111). This orientation towards personhood in social interaction is not a naturalistic one. Therefore, the principles of organization of personhood as well as the question of which capacities someone

\footnotetext{
${ }^{13}$ Tadros has described a similar fundament of criminal responsibility and has named it "status-responsibility". Indeed, status and personhood are comparable concepts. See Tadros $(2005,21)$.

${ }^{14}$ This debate cannot be examined here in detail. But see, e.g., Green (2014).
} 
has are not to be defined ontologically (Jakobs 1976, 20, 31; Jakobs $2005,258)$. The attribution of abilities is a normative procedure within a particular social system at a given time. As such, the concept of personhood is variable in principle. ${ }^{15}$ In this context, a number of voices speak about something we could call normative responsiveness or normative competence as a precondition of blameworthiness (Hörnle 2013). We only consider someone a moral and legal agent if they understand the expectations which are addressed to them and can understand responsibility for wrongdoing as well as the "communicative enterprise of punishment" (Duff 2001, 89; Keating et al. $2014,139)$. We assume the members of our society to be self-referential (Teubner \& Zumbansen 2000) as well as rational. Thus, only such an addressee to whom we ascribe this very basic competence is an addressee towards whom we hold certain normative expectations. To underline this fact with a drastic example: We do not consider a tree to have the chance to act differently or to fulfil normative standards. Therefore, a tree will not disappoint normative expectations. It is simply not a person. Of course, the questions of personhood we mainly face in criminal law are by far more complex than this example.

The debate about personhood in criminal law is widely known in the context of corporate liability and varies greatly among different legal orders. ${ }^{16}$ This debate is known and will not be further outlined here. However, there are other discussions where we deal with the question of whether someone is a qualified person for normative destabilization. Most legal orders do not consider children below a certain age to be capable addressees of normative expectations and they are not regarded to have the status of sufficiently responsible agents (Tadros 2005, 21). If they do not comply with a norm, it is explained by their general non-qualification and not by their personal mistake. Apart from that, there are also stages of insanity, where we principally consider someone not to be a capable member of com-

\footnotetext{
${ }^{15}$ This potential of variability can be observed or at least be interestingly discussed within the recent debate about the potential responsibility of robots or artificial intelligence somewhen in the future. See, e.g., Gless et al. (2016) and Simmler \& Markwalder (2017); Simmler \& Markwalder (2019) .

${ }^{16}$ Most Western legal orders have meanwhile recognized the possibility of criminal corporate liability, although the justifications and concrete models differ relevantly. Still, for example in Germany, where the principle of culpability is upheld very strongly, this doctrine has not been accepted yet.
} 
munication and not just in regard to one concrete situation but rather as a negation of this basic personhood. ${ }^{17}$ Whether someone is a participant of social interaction and a full member of society in this sense is decided in interrelationship with the quality of personhood. Only such a full member can question a norm, and only a questioned norm asks for punishment. Therefore, personhood is an indispensable element of the process of placing blame. Within the category of blameworthiness in criminal law, the isolation of the offender as the agent of the destabilization allows the conflict to be shifted to a subsystem (Jakobs 1976, 13). Only offenders who are qualified as an originator of destabilizing communication can serve this purpose.

\subsubsection{Competence Element}

The element I named competence element relies on the general accountability discussed previously but contains another condition, which is needed to call someone to account. As already pointed out, shifting a mistake to a sub-system requires the ascribed capacity to act differently. This is not only relevant for the general condition of normative destabilization but rather for the judgement of the very concrete communication at hand. ${ }^{18} \mathrm{We}$ do not consider someone responsible for an act if the disappointment can be explained otherwise because of a situational excuse. Personal imputation therefore begins with the distribution respectively the attribution of competence between the offender and other parties (Jakobs 2004). This element is not any less relative than the preceding one. The mechanisms of finding excuses for a disappointed normative expectation allow for a certain range of assumptions, which can differ over time as well as between different social orders. In fact, the disappointment in these constellations emerges from a generally capable actor who might even have questioned the norm with her or his act (for example by voluntarily driving too fast). Therefore, the expressive behavior as well as the originator are basically qualified to destabilize the norm. However, there might be a lack of competence to have acted differently in that situation, and thus, we can explain the questioning of the

${ }^{17}$ The difficulty of drawing that line clearly shows once again that personhood is relative and can furthermore change over time, e.g. if new neuroscientific findings relativize certain capabilities.

${ }^{18}$ See Tadros $(2005,124)$ explaining the differences between "status-responsibility" and "attribution-responsibility" by pointing out that there may be agents who lack responsibility for their actions in general due to their status and are entitled to a general exemption while others are only entitled to specific situational excuses as has already been addressed within the personhood element. 
validity of the norm in other ways besides personal fault (for example because the speeding happened in an intoxicated state).

There are certain fields of criminal law doctrine that affect this element and that cannot be outlined here in detail. In general, most of these topics are dealt with in the category of defenses, even though just the excusing ones and not the justifying ones (Ashworth 2011, 541; Blomsma \& Roef 2016, 157-58). The Common Law doctrine does not draw a clear line between these two types. Still, the difference matters regarding normative destabilization. The field of excusing defenses concerns cases in which the act itself is wrongfully committed and is principally qualified to communicate the invalidity of the norm (e.g. the actor wanted to drive too fast and communicated non-respect towards the norm), but in which this communication can be excused because of the affected reasonableness or inevitability to act in this way. This category can contain, for example, cases of reduced liability due to diminished capacity or insanity, excusing (but not justifying) duress, or inevitable mistakes of law. ${ }^{19}$ These excuses do not affect the wrongfulness of the act but they allow to present the wrongful act in a different, better light. Therefore, they influence the identification of the personal mistake generally as well as the identification of the extent of this personal mistake. With that said, it becomes clear that while personhood is something binary (it is present or it is not), competence can also be at hand gradually, what makes this element especially relevant for the second purpose of the fault requirement, the demand of proportionality.

What counts as a valid excuse, which is considered to ascribe the destabilization not to the agent of the act but rather (fully or partly) to her or his situational incapacity due to external circumstances, is, to point that out again, highly relative and therefore a frequent topic of debate. English and US-American criminal law can be called comparatively strict regarding the tolerance within the competence element. ${ }^{20}$ The attribution of normative capacities emerges from social interaction. This concerns not only general competence but also the competence to have acted differently in a concrete situation. The essence of the competence element for the mechanisms of placing blame consists in differentiating the cases in which the disappointed

\footnotetext{
${ }^{19}$ On the other hand, mistakes of fact as we will see affect the sent message due to the act and not the situational capacity of the originator.

${ }^{20}$ For example towards mistakes of law, the acceptance of reduced insanity or diminished capacity, which are more widely taken into account in most Civil Law orders.
} 
expectation can be explained by situational circumstances from the cases in which a personal fault is identified as an explanation and therefore punishment becomes necessary in order to re-stabilize the norm.

\subsubsection{Message Element}

After having outlined the importance of imputing the destabilizing communication to a person within the system (personhood element) and of the assessment that this imputation is not torpedoed by a situational incompetence (competence element), it is important to see as well that the purpose of placing blame is furthermore to identify whether the communication itself is questioning and therefore destabilizing the norm (message element). Within this category, we deal with the subjective conditions that mark the disappointing behavior as wrongful. Usually, these are the mens rea-elements. This matter of fact answers the question of whether a certain information is communicated and whether it is suited to question the validity of the norm. While the objective elements of the offense (actus reus) serve to identify whether a normative expectation has been disappointed in the first place, this category tells us if the disappointment destabilizes the normative structure due to the message sent by the offender's act. The social system identifies the offender's wrongful attitude towards the norm (Bleckmann 2002, 139). Only this expressed disregard affects the stability of the norm and therefore asks for punishment in return.

Again, I want to point out that the assessment of the question of whether there is a destabilizing communication is not an assessment of a mental state (or its absence) in an ontological sense. However, the impossibility of discovering the true mental state of someone does not matter for social interaction. The key, thus, lies in understanding the creation of social meaning and social sense (Bleckmann 2002, 147; Jakobs 2004). To find out if an offense was committed with intent or not means to find out what attitude towards the norm at hand was communicated and which message has been sent. Only if a destabilizing message has been communicated, someone will be called to account. That is generally the case if the offender has acted with intent and knowledge. In this case, she or he has willfully disappointed the normative expectation, assuming that no justifying defenses can be presented. Furthermore, it is the case if the offender has acted recklessly or negligently and if she or he therefore expressed a deficit of motivation to sufficiently respecting the norm and to 
complying with the normative expectation. There is of course a relevant difference in intensity of the message, if an offender has acted with intent and actively pursued to impair a legally protected good, or if an offender neglected his duties and therefore has to take responsibility for a caused damage. Both behaviors represent a violation of a norm, the later does, however, question the norm less pronounced.

Such a message on the other hand is not sent if the person in question has acted willfully and knowingly but the existence of special circumstances (justifications) nevertheless allow to signify that she or he was not questioning the validity of the norm and its stability therefore remains untouched. Justifications are generally regarded to result in a determination that there was no wrongful act (actus reus) in the first place. ${ }^{21}$ This is the case, for example, if the actor intentionally bodily injured someone else, but only did that to save her or his own life in self-defense. The act does not communicate that she or he does not respect the norm that one should not make use of physical harm. The non-compliance with this expectation is not understood as a negation of a normative expectation, because there is no such expectation under these special circumstances. The actor does not endanger the validity of a norm and no punishment is needed.

There are however defenses that affect directly the subjective elements of the offense. In these cases, an expectation is objectively disappointed, the disappointment may however not actually communicate a questioning of the norm at hand. One controversial example are mistakes of fact. In general, it is clear that an offense committed while being mistaken with regard to a relevant fact is not suited to destabilize a norm. When one wants to shoot an animal but shoots a human instead, she or he does not question the norm that people should not be killed. Not to say that this person might not have destabilized another norm in this very example, but she or he did not destabilize the norm concerning intentional homicide. In this case, no punishment is needed to guarantee the stability of this norm. Consequently, no blame can be placed with regard to this norm. However, this example outlines another characteristic of the principle of culpability. It does not just say nulla poena sine culpa. It additionally states that culpability has to stand in a direct relationship with the punishment. The punishment, which is justified by personal fault, is the punishment that stabilizes the norm questioned by the

\footnotetext{
${ }^{21}$ While excusatory defenses affect the blameworthiness of the defendant in acknowledging the wrongfulness of the act. See Keating et al. (2014, 236-37).
} 
offender - not just any norm. If the sequence of destabilization by the offense and stabilization by the punishment are not in line, this purpose is not fulfilled.

It has to be discussed if these sociological observations are in line with the classic distinction between wrongfulness and blameworthiness. Indeed, the message element is concerned with both. One part of this category is to determine if the act is wrongful in the sense that the subjective or mens rea-elements of the offense are constitutive of wrongfulness. Only an act communicating this wrongfulness can disappoint a norm in the first place. This part is a process of defining if the act is potentially suited to express a negation of a norm. However, there is another step, where we judge if the act is not only suited to express a negation of a norm but furthermore examine if this is really expressed by the offender. This second part lies in the realm of blameworthiness, if we consider the classic distinction. It is a judgment made by the receivers of the message. Hence, these subjective elements and mentes reae hold a position of double importance, although in social practice both aspects may usually be assessed jointly. ${ }^{22}$ Assessing mens rea in a certain case is therefore not only part of assessing the infraction of a normative expectation but also of determining the concrete way and extent of the questioning of the norm by the offender. Her or his responsibility for the destabilizing effect of his message, or more precisely the content of the message itself, is highly depending on the ascribed mental state.

The message element is where we decide if a destabilizing communication is there or not. If such a communication is present, it is furthermore the place where we identify its essence. Identifying the message of course goes hand in hand with the ascription of motives and knowledge and is therefore not independent of the assessment of the offender's competence. The three described elements interact with

\footnotetext{
${ }^{22}$ It has been discussed intensively - especially in German literature - if the different mental states are only to be treated as elements of wrongfulness but not of blameworthiness. Having the function of placing blame in mind, I refuse to ignore the importance of mens rea for the described mechanism not just in determining if there is a wrongful act but within one breath if there is an act communicating a questioning of the norm due to personal fault. Of course, it could be argued otherwise in pointing out the distinction of the assessment of wrongdoing and the value judgement of this wrongdoing. I hope that I have been clear in stating that there is this difference, but from an expressive point of view it might be less distinctive and more interrelated than it seems. Therefore, describing the mechanism of placing blame has to take into account not only the imputation to a competent person but also the question of the expressed message itself and its destabilizing potential.
} 
each other within the mechanism of placing blame. However, the traditional categories used within legal doctrine (actus reus, mens rea and defenses in the Common Law order) sometimes fail to indicate the interrelations and dynamics of placing blame, even though they successfully and widely represent the main questions at hand. Generally, applying these doctrines is nothing else than trying to evaluate if there is a destabilization of a norm which gives rise to a need for placing blame.

\section{INTERRELATION OF CRIMINALIZATION, PUNISH- MENT AND CULPABILITY}

Before discussing the implications of this analysis of the mechanism of placing blame for engaging with criminal law in scholarship and in legal practice, I want to summarize what has been stated so far and how these functional insights relate to each other. The function of criminal law lies in the (counterfactual) stabilization of certain specially protected normative expectations in order to guarantee the continued existence of these norms even in cases of disappointments. It pursues this aim in using its specific instrument of punishment. The distinctive feature of punishment unquestionably consists in its extraordinary strength in stabilizing selected norms, for which e.g. the compensation offered by tort law would not be sufficient. However, this distinctive feature requires the imputation of personal responsibility, whereas other legal systems do not rely on that mechanism of calling someone to account due to her or his personal fault.

This functioning of criminal law is not arbitrary. As we have seen, certain structures provide the foundations of the mechanism of placing blame within the system. They are historically stable in their position while being socially relative in their concrete content. The elements I have described could be named or ordered in a different manner. Their essence, however, lays the fundament of the criminal law system's operations. Every communication of this social system seeks to answer the binary question of criminal/non-criminal as well as to determine punishment as the system's output. Placing blame as the modus operandi of criminal law is therefore designed to serve the function of criminal law, i.e. to stabilize norms by providing punishment.

This leads me to an essential paradox, which lies at the core of criminal law: There is only a destabilization of a norm, which requires punishment, if there is personal fault. Without fault, the disap- 
pointment can be processed otherwise. No one has to be called to account and to be punished. Then again, personal fault requires a destabilization of a norm. There is no need for placing blame if there is no norm that has been challenged. Thus, personal fault and normative (de)stabilization have to be seen as an interrelated, systemic phenomenon within the criminal law system. This interplay is essential for the distinctiveness of the historical system, its functioning and its boundaries.

The remaining question is what kind of normative expectations benefit from this special protection and, in turn, what kind of disappointments ask for punishment in the first place. This is not decided within the criminal law system but externally determined by the political system. It is the objective of theories of criminalization to find patterns and touchstones of which conduct should be criminalized and which should not. This question cannot be outlined further here. However, it is important to notice two things in this context. First, it must be recognized that the question of which norms are to be protected is a question that lies outside the process of placing blame and therefore outside criminal law's operation. It is predetermined. Second, it is important to acknowledge that the question of what ought to be criminalized (the question of the system's boundaries) is systemically linked to the process of placing blame. This is due to the fact that this special sequence of placing blame and stabilizing norms by punishment takes place only within the boundary of the system. That implies, additionally, that every breach of a criminal norm must follow this special sequence, i.e. the modus operandi of criminal law. If this modus of placing blame functionally is neglected, the system's social purpose could not be fulfilled adequately and criminal law could potentially be destabilized on the long run. Understanding this systemic interrelation leads to the conclusion that punishment must always be the result of the process of placing blame. When society makes use of this specific social system in order to protect certain norms (by criminalizing their breaches), the system will follow its operations in order to fulfill this task. That means it will follow the principle of culpability. Only if an adequately competent person questioned a norm effectively (i.e. in a blameworthy manner), punishment is necessary and legitimate. Only if punishment follows this principle, it can serve its purpose and stabilize norms. Only then is placing blame functional within the criminal law system and within society. Or, to put it otherwise: nulla poena sine culpa. 


\section{DOCTRINAL IMPLICATIONS: TOWARDS SOCIOLOGI- CAL LEGAL THOUGHT}

As I have examined, the principle of culpability implies two rationales within the system's mechanism of placing blame: First, there must be a destabilization of a norm, which can be explained by the offender's fault. If there is no disappointed norm or the disappointment does not ask for punishment (because one of the elements is missing), we will not place blame. Second, the principle requires a proportional connection between the damage caused to the validity of the norm (due to the offender's fault) and the punishment. To follow this aim of determining the system's output in line with its function, the social system's operations include the three described elements to define if a punishment is needed to fulfil the system's main function and what punishment is needed to repair the damage caused (or more precisely: to prevent the damage in the first place). A punishment that is harsher than it is necessary for stabilizing the normative expectation would be not just ineffective but furthermore hard to legitimate. It would be dysfunctional. A punishment that is not harsh enough to compensate for the destabilization of the norm would be ineffective as well. Punishment would fail its purpose. Punishment and blame must therefore stand in a balanced proportion. They must be placed functionally.

Usually, this functionality is achieved with the help of offense constructions and legal frames, which allow identifying appropriately if the required conditions are present in a certain case. However, there are constructions within the doctrine of criminal law in the context of which the capability of this appropriate identification remains contested. Usually, we call these cases strict liability. This observation of the system's standard mechanism therefore is not only an observation, i.e. a description. As deviations and dysfunctionalities are generally possible, the call for a functional placement of blame is also an ideal, i.e. a normative demand. The presented functional analysis and its results can now explicitly serve as a framework to appraise such doctrines and dogmatic constructions. Its value therefore does not only rest on insights on the functioning of this social system. On this basis, a functional assessment of doctrinal questions becomes possible as well.

Although such an approach cannot be developed in detail here, it can be stated that the benchmark of such a normative evaluation of existing doctrines based on sociological analysis - a sociological legal 
thought - would unify descriptive findings and normative reflection. It would therefore allow criminal legal scholarship not to rely solely on arguments of justice or injustice, but in addition on our existing social system, its functioning, and its necessities.

This examination did however not deal with the question of how the criminal law of an ideal world looks like (if such a world would need a criminal law in the first place). Instead, it set out how criminal law in Western legal orders actually function in our time. The relevance of punishment for the handling of normative disappointments and for the upholding of social order in this existing system is undeniable. This should not mislead, however, to the conclusion that the stabilization of norms does always include a fixation of the status quo. Describing the functioning of society does not aim at conserving this kind of imputing individual responsibility for all times. Evolution and, as stated in the beginning of this article, a critical-emancipatory confrontation remains possible and desirable. The implication of a functional analysis of criminal law therefore does not consist in a statement that the observed mechanisms are carved in stone. Rather, they are our social reality at this time. They have therefore to be taken into account whenever one is confronted with criminal law, its theoretical foundation, its doctrines, and its interpretation.

\section{CONCLUSION}

Originally, the core reason for upholding the principle of culpability was that it is supposed to prevent the state from abusing its power over individuals and to justify punishment only on firm grounds. This article now presented an additional argument for why upholding this principle is important. Placing blame following this principle warrants that punishment is only imposed where it is necessary for the protection of the validity of the norms in question. It therefore serves a specific purpose regarding the social order within society. Upholding the principle of culpability and consequently criticizing deviating doctrines, one does not only have to rely on moral arguments of individual fairness, but also finds a backup in the social functioning of our society and its criminal law sub-system. As a main achievement of liberal conceptions, the principle of culpability marked the boundary between criminal law and other fields of law, which are less coercive. Disrespecting it permanently will eventually result in a destabilization of this social system, as it will not be able to 
fulfil the function for which society has differentiated criminal law in the first place.

The article thus revealed that the principle of culpability is more than solely a normative principle or an ideal. It is the criminal law system's basic functioning, its modus operandi. Deviating from the standard mechanisms of placing blame is dysfunctional, i.e. it does not serve the overall aim of stabilizing norms. The function of criminal law, which consists in the counterfactual stabilization of normative expectations, asks for operations that serve to determine the system's output (punishment) as adequately as possible, i.e. in line with this function. Now that is where the position of placing blame is to be located as well. It gains its importance solely with regard to the system's function. Placing blame and the stabilization of norms intertwine inseparably.

This examination of the function of criminal law within society and the subsequent analysis of the relevance of placing blame for the fulfillment of this function can serve as a solid ground for a systematic analysis of doctrines of criminal law. The method of systems theory and of functional analysis can generally lay the foundation for a sociologically informed criminal law theory and a sociological legal thought unifying descriptive and normative perspectives. This article tried to present a first step in this direction. Revealing the stabilization of norms by means of punishment as the function of criminal law and the placement of individual responsibility as its key mode of operation, this article aimed at adding to the continuing debate on the essential questions of criminal law theory. It was shown that for the fulfillment of criminal law's function placing blame is not only a useful but rather a necessary condition. Therefore, the status of placing blame derives directly from its functional necessity and from its social importance for the stabilization of norms.

\section{REFERENCES}

Amstutz, Marc \& Andreas Fischer-Lescano, eds. (2013) Kritische Systemtheorie: Zur Evolution einer normativen Theorie. Bielefeld: transcript Verlag.

Ashworth, Andrew (2011) "United Kingdom," in K. J. Heller \& M. D. Dubber eds., The Handbook of Comparative Criminal Law. Stanford, CA: Stanford University Press.

Baurmann, Michael (1998) "Vorüberlegungen zu einer empirischen Theorie der positiven Generalprävention,” in B. Schünemann, A. von Hirsch \& N. Jareborg 
eds., Positive Generalprävention: Kritische Analysen im deutsch-englischen Dialog. Heidelberg: C. F. Müller.

Bleckmann, Frank (2002) Strafrechtsdogmatik - wissenschaftstheoretisch, soziologisch, historisch: Das Beispiel des strafrechtlichen Vorsatzes. Freiburg im Breisgau: Edition Iuscrim.

Blomsma, Jeroen \& David Roef (2016) "Forms and Aspects of Mens Rea," in J. Keiler \& D. Roef eds., Comparative Concepts of Criminal Law, 2nd ed. Cambridge: Intersentia.

Brown, Darryl K. (2012) "Federal Mens REA Interpretation and the Limits of Culpability's relevance," 75/2 Law and Contemporary Problems 109-133.

Duff, R. A. (2001). Punishment, Communication and Community. Oxford: Oxford University Press.

Durkheim, Émile (1984) The Division of Labor in Society. London: Macmillan. (Original: Durkheim, Émile (1893) De la division du travail social. Paris: Presses Universitaires de France).

Farmer, Lindsay (2016) Making the Modern Criminal Law: Criminalization and Civil Order. Oxford: Oxford University Press.

Fletcher, George P. (1998) Basic Concepts of Criminal Law. Oxford: Oxford University Press.

Gardner, John (2005) "Wrongs and Faults," in A.P. Simester ed., Appraising Strict Liability. Oxford: Oxford University Press.

Gless, Sabine et al. (2016) "If Robots Cause Harm. Who Is to Blame? Self-driving Cars and Criminal Liability," 19/3 New Criminal Law Rev. 412-436.

Gómez-Jara Díez, Carlos (2005) "Die Strafe: Eine systemtheoretische Beobachtung" 36 Rechtstheorie 321-340.

Green, Thomas A. (2014) Freedom and Criminal Responsibility in American Legal Thought. Cambridge: Cambridge University Press.

Hall, Arthur D. \& Robert E. Fagen (1956) "Definition of System," 1 General Systems $18-28$.

Hart, H. L. A. (2008) Punishment and Responsibility. Essays in the Philosophy of Law, 2nd ed. Oxford: Oxford University Press.

Hörnle, Tatjana (2013) Kriminalstrafe ohne Schuldvorwurf: Ein Plädoyer für Änderungen in der strafrechtlichen Verbrechenslehre. Baden-Baden: Nomos Verlag.

Jakobs, Günther (1976) Schuld und Prävention. Tübingen: Mohr.

Jakobs, Günther (1993) Strafrecht Allgemeiner Teil. Die Grundlagen und die Zurechnungslehre, 2nd ed. Berlin: De Gruyter.

Jakobs, Günther (1995) "Das Strafrecht zwischen Funktionalismus und "alteuropäischem" Prinzipiendenken," 107 Zeitschrift für die gesamte Strafrechtswissenschaft (ZStW) 843-67.

Jakobs, Günther (2004) "Imputation in Criminal Law and the Conditions for Norm Validity" 7/2 Buffalo Criminal Law Review 491-511.

Jakobs, Günther (2005) "Individuum und Person. Strafrechtliche Zurechnung und die Ergebnisse moderner Hirnforschung," 117 Zeitschrift für die gesamte Strafrechtswissenschaft (ZStW) 247-66.

Keating, H. M. et al (2014) Clarkson and Keating Criminal Law: Text and Materials, 8th ed. London: Sweet \& Maxwell.

Killias, Martin (1980) "Muss Strafe sein? Überlegungen zur Funktion von Sanktionen aus sozialpsychologischer Sicht," 97 Zeitschrift für schweizerisches Strafrecht (ZStrR) 31-57. 
Kleinfeld, Joshua (2016) "Reconstructivism: The Place of Criminal Law in Ethical Life," 129/6 Harvard Law Rev. 1485-1565.

Luhmann, Niklas (1974) Rechtssystem und Rechtsdogmatik. Stuttgart: Kohlhammer.

Luhmann, Niklas (1981) Ausdifferenzierung des Rechts: Beiträge zur Rechtssoziologie und Rechtstheorie. Frankfurt am Main: Suhrkamp.

Luhmann, Niklas (1992) "Operational Closure and Structural Coupling: The Differentiation of the Legal System," 13 Cardozo Law Rev. 1419-1443.

Luhmann, Niklas (1995a) Social Systems. Stanford, CA: Stanford University Press. (Original: Luhmann, Niklas (1984) Soziale Systeme. Frankfurt am Main: Suhrkamp).

Luhmann, Niklas (1995b) Funktionen und Folgen formaler Organisation, 4th ed. Berlin: Duncker \& Humblot.

Luhmann, Niklas (2004) Law as a Social System. Oxford: Oxford University Press (Original: Luhmann, Niklas (1993) Das Recht der Gesellschaft. Frankfurt am Main: Suhrkamp).

Mastronardi, Philippe (2009) Angewandte Rechtstheorie. Stuttgart: UTB.

Maturana, Humberto R. \& Francisco J. Varela (1980) Autopoiesis and Cognition: The Realization of the Living. Dordrecht: D. Reidel.

Merton, Robert K. (1957) Social Theory and Social Structure, 3rd rev. ed. Glencoe: Free Press.

Mitchell, Barry (1999) “In Defence of a Principle of Correspondence," Criminal Law Rev. 195-205.

Parsons, Talcott (1962) "The Law and Social Control," in W. M. Evan ed., Law and Sociology: Exploratory Essays. Glencoe: Free Press.

Parsons, Talcott (1951) "Some Fundamental Categories of the Theory of Action: A General Statement," in T. Parsons \& E. A. Shils eds., Toward a General Theory of Action: Theoretical Foundations for the Social Sciences. New Brunswick/London: Transaction Publishers.

Popitz, Heinrich (1980) Die normative Konstruktion von Gesellschaft. Heidelberg: Mohr Siebeck Verlag.

Röhl, Klaus F. (2001) Allgemeine Rechtslehre: Ein Lehrbuch, 2nd ed. Cologne: Carl Heymanns Verlag.

Schneider, Hendrik (2004) Kann die Einübung in Normanerkennung die Strafrechtsdogmatik leiten? - Eine Kritik des strafrechtlichen Funktionalismus. Berlin: Duncker \& Humbolt.

Simmler, Monika (2018) Normstabilisierung und Schuldvorwurf. Bern/Berlin: Carl Grossmann Verlag.

Simmler, Monika \& Nora Markwalder (2017) "Roboter in der Verantwortung," 129 Zeitschrift für die gesamte Strafrechtswissenschaft (ZStW) 20-47.

Simmler, Monika \& Nora Markwalder (2019) "Guilty Robots? - Rethinking the Nature of Culpability and Legal Personhood in an Age of Artificial Intelligence," 30/2 Criminal Law Forum 1-31.

Tadros, Victor (2005). Criminal Responsibility. Oxford: Oxford University Press.

Teubner, Gunther (1993) Law as an Autopoietic System. Oxford: Blackwell. (Original: Teubner, Gunther (1989) Recht als autopoietisches System. Frankfurt am Main: Suhrkamp).

Teubner, Gunther \& Zumbansen, Peer (2000) "Rechtsentfremdungen: Zum gesellschaftlichen Mehrwert des zwölften Kamels" 21 Zeitschrift für Rechtssozioloie 189-215. 
Theile, Hans (2009) Wirtschaftskriminalität und Strafverfahren. Heidelberg: Mohr Siebeck Verlag.

Wachter, Mattias (2015) Das Unrecht der versuchten Tat. Heidelberg: Mohr Siebeck Verlag.

Weizel, Hans (1969) Das deutsche Strafrecht: Eine systematische Darstellung, 11th ed. Berlin: De Gruyter.

Publisher's Note Springer Nature remains neutral with regard to jurisdictional claims in published maps and institutional affiliations. 